\title{
Morphology and ecology of the kalyptorhynch Typhlopolycystis rubra (Plathelminthes), an inmate of lugworm burrows in the Wadden Sea
}

\author{
U. Noldt ${ }^{1} \&$ K. Reise ${ }^{2}$ \\ ${ }^{1}$ II. Zoologisches Institut und Museum der Universität Göttingen; Berliner Straße 28, \\ $D$-3400 Göttingen, FRG \\ ${ }^{2}$ Biologische Anstalt Helgoland, Litoralstation List; D-2282 List/Sylt, FRG
}

\begin{abstract}
Typhlopolycystis rubra, a new species of the taxon Polycystididae (Plathelminthes, Kalyptorhynchia), is described. The red species is characterized by copulatory hard structures which consist of a proximal girdle and 2 similar sized stylets. T. rubra occurs in intertidal sand near the island of Sylt in the North Sea. Here, it is virtually confined to the lowest parts of lugworm (Arenicola marina) burrows, where it aggregates in the coarse grained sand around the feeding pocket areas. This is an extremely narrow spatial niche within the sulfide layer of sediment. Population size over a period of 7 years is the most constant one among all species of Plathelminthes living on the tidal flat. The ability of $T$. rubra to endure unsuitable conditions inside a cyst may contribute to this remarkably low population variability.
\end{abstract}

\section{INTRODUCTION}

Current conjectures on the number of existing species go up to 30 or 40 million (see Lewin, 1983; Wilson, 1985; May, 1986). Of these, approximately 1.7 million have been described, and knowledge on behaviour or ecological requirements is probably limited to $<1 \%$ of the real number. Particularly with regard to ecology, it seems doubtful whether generalizations based on such a small fraction can achieve high reliability.

For example, the benthos in the Wadden Sea has been characterized as poor in species, dominated by a few strong populations which are well adapted to this harsh environment (cf. Beukema, 1976; Wolff, 1983). However, this conclusion is mainly based on the tidal flat fauna that can be retained by a 1-mm sieve. Equally detailed studies on meiofauna or on benthic diatoms would presumably arrive at a completely different statement. With every new species, new phenomena of general interest may be discovered.

Here we report on a new species of free-living Plathelminthes ("Turbellaria") which is predictably found in the lowest parts of lugworm (Arenicola marina) burrows. Of all Plathelminthes on a sandy tidal flat near the island of Sylt, it has shown the most constant population size over the last seven years; yet its spatial niche is one of the smallest. This robin worm is capable of encystment, which is a novel phenomenon of free-living Plathelminthes living in the sulfide system of tidal flats.

Typhlopolycystis rubra was formerly referred to as Typhlopolycystis sp. in Reise (1983a, 1983b; 1984; 1985) and Scherer (1985). 


\section{MATERIAL AND METHODS}

The type locality is a sandy lugworm flat in the lower tidal zone of the eastern part of Königshafen, island of Sylt (see Reise, 1984; Figs 2, 3). In June 1984 thirty specimens were collected. 20 serial sections were prepared and stained with Delafield's iron hematoxylin. 5 specimens were preserved as whole mounts (embedded in polyvinyllactophenol). The holotype is one sagittal series (P1991). Paratypes (P1992-P2000) include 6 other serial sections and 3 whole mounts. The material is deposited at the Zoological Museum of the University of Göttingen.

Burrows of the lugworm were dug up with a spade. Samples of $2 \mathrm{~cm}^{3}$ each were obtained from the region of the feeding pocket and the horizontal gallery. These small samples were simply diluted with filtered seawater, partitioned over a set of about 12 petri dishes, and specimens were picked up with a pipette under the dissecting microscope. No sieves were used and only live material was investigated.

\section{MORPHOLOGY}

\section{General morphology}

The smallest free-living individual encountered attained a length of $0.45 \mathrm{~mm}$, and the largest one up to $1.6 \mathrm{~mm}$. On average, length is $1.0 \mathrm{~mm}$ and maximum width is $0.15 \mathrm{~mm}$. When crawling, the body is elongated; while swimming, individuals contract. All movements are very slow.

Most of the 516 individuals found at the type locality are bright red, a few pale or brownish. About one third were found curled up within spherical cysts of 0.4 to $0.5 \mathrm{~mm}$ in diameter. Cysts consist of a transparent mucus layer with adhering detritus, $\mathrm{CaCO}_{3}$ needles from dissolved mussel shells, and sand grains. Repeated probing with a needle caused the animals to break through the mucus envelope, to crawl or swim away leaving the empty cyst behind. Bright light and increased temperature under the dissecting microscope also induced animals to leave their cysts.

Large adhesive glands (cgl) are located in the posterior part of the body (Fig. 1). Other adhesive organs are lacking. A few tactile cilia are present at the anterior body tip. The epidermis and the cilia form layers of $6 \mu \mathrm{m}$ width. The basal lamina is $3.0 \mu \mathrm{m}$ (medial body) to $4.5 \mu \mathrm{m}$ (body tips) thick. The epidermal nuclei are scattered, the minute pigment granules are concentrated in the periphery of the epidermis. The subepidermal musculature consists of a fine internal longitudinal and an external circular muscle layer. One pair of pigmented eyes is located in the anterior region of the brain. Two basophilic frontal glands (fgl) with fine secretion granules lie caudally to the brain.

\section{Proboscis}

The proboscis (Figs 2,5 ) is $250-280 \mu \mathrm{m}$ long ( $\triangleq$ about $1 / 5$ of the body length). In live specimens $25-35 \mu \mathrm{m}$ are recorded for the apex, 100-110 $\mu \mathrm{m}$ for the proboscis cone, and $125-150 \mu \mathrm{m}$ for the proboscis bulb. The proboscis pouch is characterized by a high basophilic epithelium $\left(e_{3}\right)$. The nuclei are concentrated in the medial part. A sphincter surrounds the orifice of the proboscis pouch. In the posterior part of the pouch a fine 
circular muscle layer $\left(\mathrm{cm}_{3}\right)$ is located beneath the layer of longitudinal muscles $\left(\operatorname{lm}_{2}\right)$. Caudally to the sphincter 4 bundles of dilatator muscles (di), composed of several fibers, insert. The retractors of the pouch (rpp) arise at about the level of the apex.

At the juncture (j), the pouch epithelium is demarcated by the high acidophilic cone epithelium $\left(e_{1}\right)$. The apex epithelium $\left(e_{2}\right)$ is weakly stained. In both the apex and the proboscis cone, there is an underlying circular musculature $\left(\mathrm{cm}_{2}\right)$. The proboscis bulb is externally lined with 50 strong, regularly distributed longitudinal muscles $\left(\mathrm{lm}_{1}\right.$; rectangular in cross-section). Internally, beneath the basal lamina of the bulb, a strong circular musculature $\left(\mathrm{cm}_{1}\right)$ makes up about $1 / 10$ of the proboscis diameter. In cross-section, numerous cone retractor muscles (rc) are concentrated in the central part of the proboscis (Figs 2, 17, 18). Six bundles of fixator muscles (fi) insert at the medial proboscis bulb and run rostrad to the integument. Between those insertions the 6 longitudinal packages of mantle cells (mc) are located. Each package contains up to 12 nuclei. Caudally to the fixator muscles 3 pairs of proboscis retractors (rpr) arise, each one composed of 3-5 strong fibers. Acidophilic proboscis glands (pgl) are situated caudally to the brain and empty into the proboscis node. At the node, 4 pairs of protractors (pro) insert. They run anteriad and insert at the basal lamina of the body at the level of the proboscis tip.

\section{Pharynx rosulatus}

The pharynx is located in the medial body third. The diameter is $170-200 \mu \mathrm{m}$ (live observation). The mouth opening is displaced frontally, the bulb itself is inclined from the dorsoventral axis. Three types of pharyngeal glands exist (Fig. 3). About 20 acidophilic glands $\left(\mathrm{gl}_{1}\right)$ with medium size secretion granules are located peripherally and empty close to the pharynx lip. With openings dorsal to the former, 8 basophilic glands $\left(\mathrm{gl}_{2}\right)$ with larger secretion are mainly located in the proximal bulb. Fine basophilic secretion of an unknown number of the third gland type $\left(\mathrm{gl}_{3}\right)$ is discharged into the medial pharynx lumen. The pharynx epithelium is generally thin $\left(e_{3}\right)$, but papillate $\left(e_{2}\right)$, when the bulb is contracted.

The circular musculature is composed of 35-40 external muscles (cme), about 20 muscles on the ventral part of the pharynx lip, 20-25 internal muscles (cmi), and about 10 muscles beneath the 4 pairs of cuticular knobs (ck). There is no concentration of circular fibres at the distal part of the pharynx lip. A thick longitudinal muscle layer $\left(\operatorname{lm}_{2}\right)$ is found a thin hardened epithelial layer, however, is lacking. 38 internal longitudinal fibres (lmi) insert distally at the lip and proximally beneath the cuticular knobs. The external longitudinal fibres (lme) are fine. In sagittal sections, the number of radial fibres (rm) is about 25; in horizontal sections 40 fibres are found (Figs 3, 20).

From the junction between the pharynx lip and the pharynx pouch ("Kontaktrand"), an indeterminable number of protractor muscles (php) runs ventrad to the integument. Ventrally, one pair of rostral and caudal lacunae (la) join the pharynx pouch (Figs 3,19). Each lacuna contains 3 large nuclei; however, a glandular matrix is lacking. The pharynx pouch is lined with a thin epithelium $\left(e_{1}\right)$ devoid of nuclei and covered by a fine longitudinal muscle layer $\left(\mathrm{lm}_{1}\right)$. The mouth opening is surrounded by a sphincter. The short esophagus is demarcated from the intestine by medially located, eosinophilic gland cells (mg), which may project into the proximal pharynx lumen. 

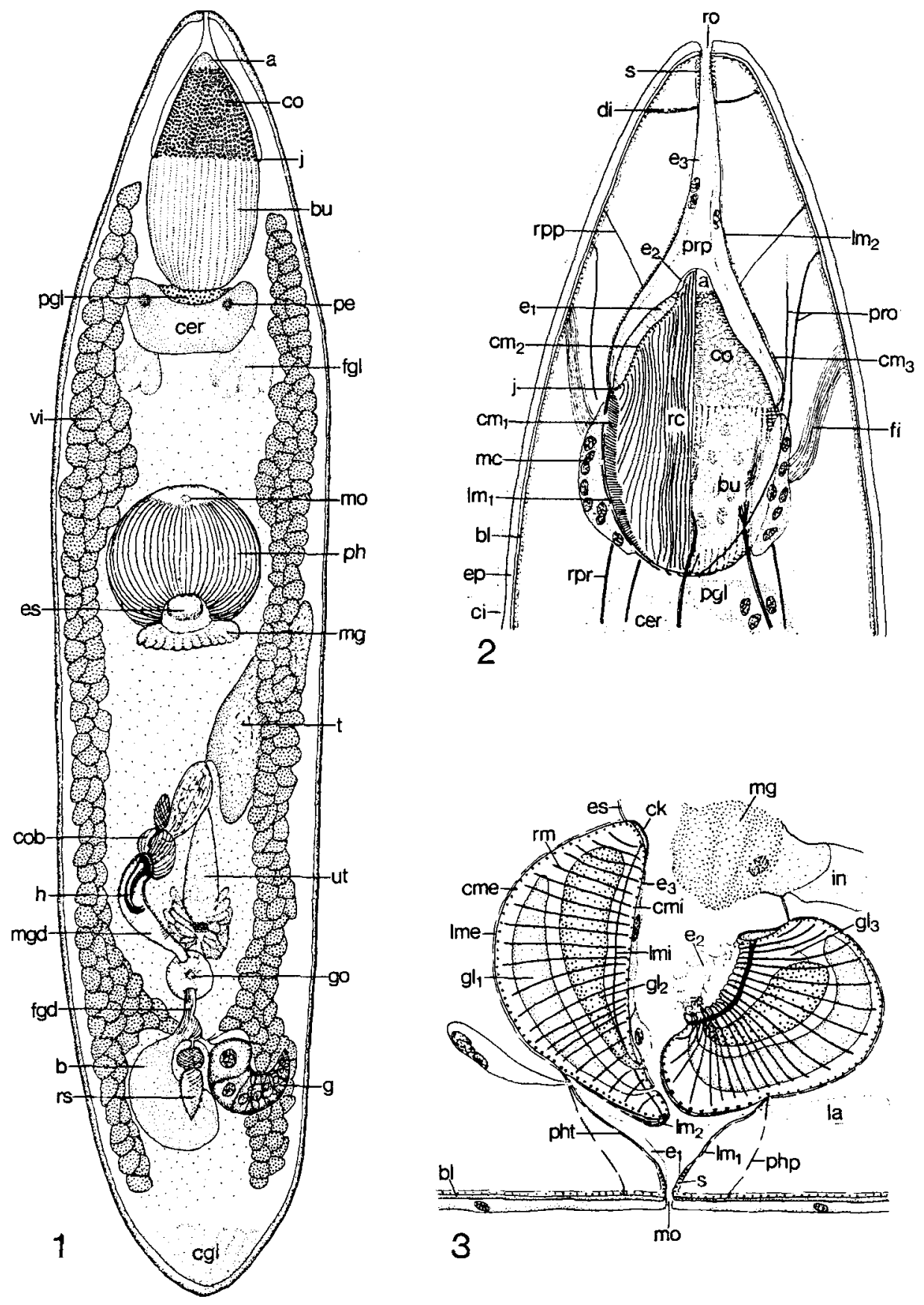


\section{Genital organs}

The long unpaired testis lies caudally to the pharynx bulb. A short, muscle-free deferent duct (vd in Fig. 10) leads to the seminal vesicle which is $150-200 \mu \mathrm{m}$ long and $40-50 \mu \mathrm{m}$ in diameter. The vesicle is septated interiorly and covered by thin longitudinal muscle fibres. It opens subterminally into the copulatory bulb (Figs 6, 10). Lined with spirally arranged musculature, the copulatory bulb is $60-70 \mu \mathrm{m}$ long and $30-40 \mu \mathrm{m}$ in diameter. The seminal duct (ds), which lacks musculature, runs acentrically on a slightly winding course through the ovoid bulb.

Three prostatic fascicles (ksf) with differently stained, but similar size secretion, lie in the copulatory bulb (Figs 10, 11, 21). The nucleated parts of the glands are located externally of the bulb. Some nucleated glands with intensively stained acidophilic secretion enter the terminal end of the accessory gland organ (av). This bulb is up to 60 $\mu \mathrm{m}$ long and lined with spirally arranged musculature. The fine muscle-free duct ( $w$ in

Figs 1-3. Typhlopolycystis rubra. 1. Organization (combined). 2. Anterior body (reconstruction from horizontal sections; proboscis contracted, left side cut off). 3. Rosulate pharynx (reconstruction from sagittal sections)

\begin{tabular}{ll} 
a & apex of proboscis \\
ac & genital atrium \\
ast & accessory stylet \\
av & accessory prostatic vesicle \\
b & copulatory bursa \\
bl & basal lamina \\
bu & proboscis bulb \\
cer & brain \\
cgl & caudal adhesive glands \\
ci & cilia \\
ck & cuticular knobs \\
cm & circular muscles \\
cme & external circular muscles \\
cmi & internal circular muscles \\
co & proboscis cone \\
cob & copulatory bulb \\
di & dilatator muscles \\
ds & seminal duct \\
$\mathrm{e}_{\mathbf{n}}$ & epithelium \\
ep & epidermis \\
es & esophagus \\
fgd & female genital duct \\
fgl & frontal glands \\
fi & fixator muscles \\
$\mathrm{g}$ & germarium, germocyte \\
$\mathrm{gl} \mathrm{n}_{\mathbf{n}}$ & glands \\
$\mathrm{go}$ & gonopore \\
$\mathrm{h}$ & copulatory hard structures \\
in & intestinum \\
$\mathrm{j}$ & juncture of proboscis \\
$\mathrm{ksf}$ & prostatic fascicle \\
$\mathrm{la}$ & lacuna of pharynx pouch \\
$\mathrm{lm}$ \\
$\mathrm{n}$ & longitudinal muscles \\
& \\
\hline
\end{tabular}

Abbreviations in the figures

$\begin{array}{ll}\text { Ime } & \text { external longitudinal muscles } \\ \text { lmi } & \text { internal longitudinal muscles } \\ \text { mc } & \text { mantle cells } \\ \text { mg } & \text { Mignot's glands } \\ \text { mgd } & \text { male genital duct } \\ \text { mo } & \text { mouth opening } \\ \text { pe } & \text { pigmented eyes } \\ \text { pgl } & \text { proboscis gland } \\ \text { ph } & \text { rosulate pharynx } \\ \text { php } & \text { protractors of pharynx } \\ \text { pht } & \text { pharynx pouch } \\ \text { pro } & \text { protractors of proboscis } \\ \text { prp } & \text { proboscis pouch } \\ \text { rc } & \text { retractors of proboscis cone } \\ \text { rm } & \text { radial muscles } \\ \text { Io } & \text { opening of proboscis pouch } \\ \text { Ipp } & \text { retractors of proboscis pouch } \\ \text { rpr } & \text { retractors of proboscis } \\ \text { Is } & \text { seminal receptacle } \\ \text { s } & \text { sphincter } \\ \text { sm } & \text { spiral muscles } \\ \text { st } & \text { stylet } \\ \text { stg } & \text { stylet girdle } \\ \text { t } & \text { testis } \\ \text { ut } & \text { uterus } \\ \text { vc } & \text { vacuol } \\ \text { vd } & \text { deferent duct } \\ \text { vi } & \text { vitellaria,vitellocyte } \\ \text { vs } & \text { seminal vesicle } \\ \text { w } & \text { muscle-free duct } \\ \text { x } & \text { diverticulum } \\ \text { y } & \text { germovitelloduct } \\ \text { z } & \text { uterine papillae } \\ & \\ \text { mate }\end{array}$



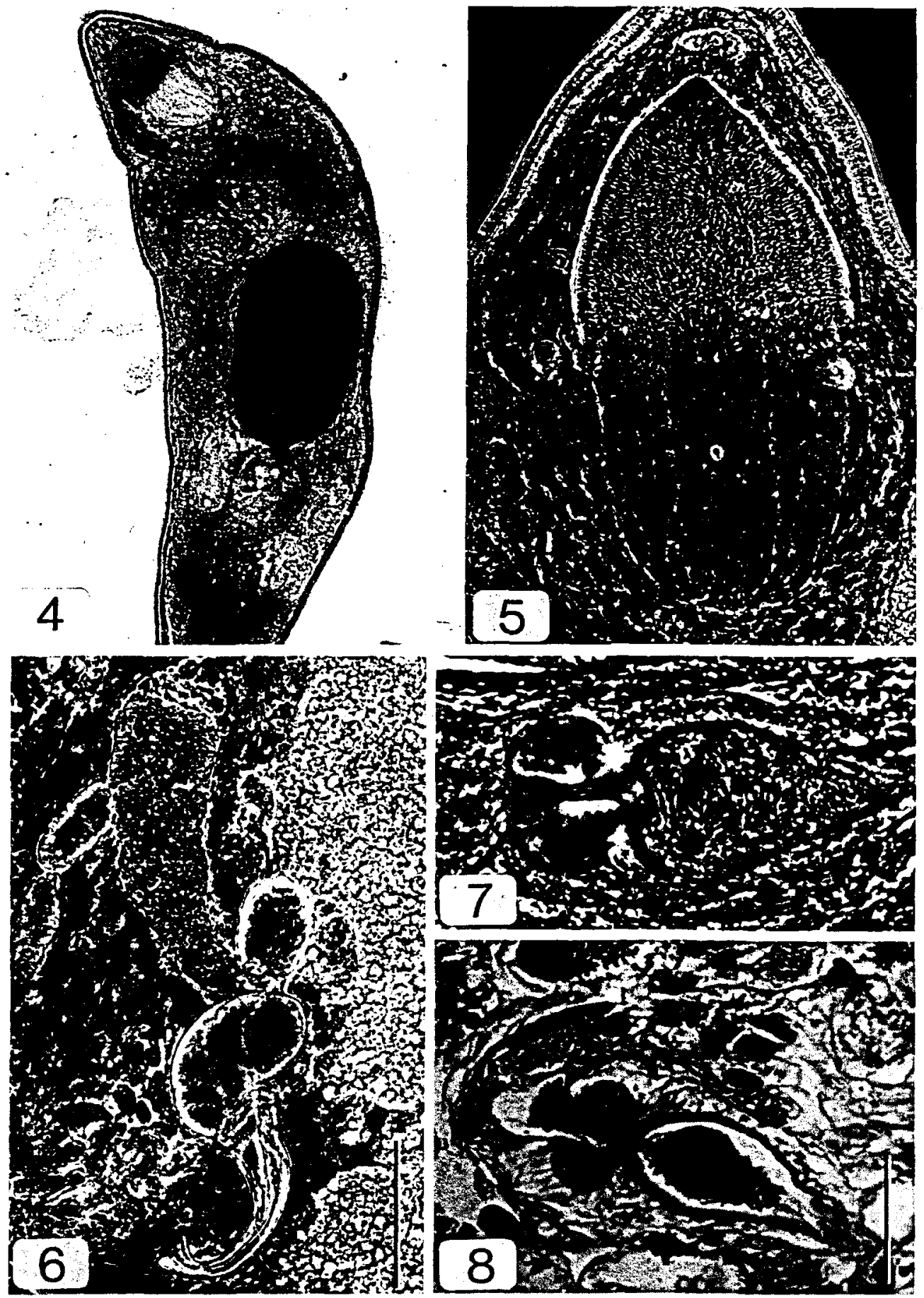

Figs 4-8. Typhlopolycystis rubra. 4. Specimen with egg-capsule. 5. Proboscis. 6. Copulatory organ. 7 and 8. Seminal receptacle. Scales: Fig. 6: $50 \mu \mathrm{m}$; Fig. 8: $20 \mu \mathrm{m}$ 
Figs 10,11 ) runs acentrically in the copulatory bulb and enters the accessory stylet proximally.

The copulatory hard structures (Figs 9, 23, 24) consist of a proximal closed girdle (stg), a sheath-like prostatic stylet (st), and a tubiform, pointed accessory stylet (ast). Both
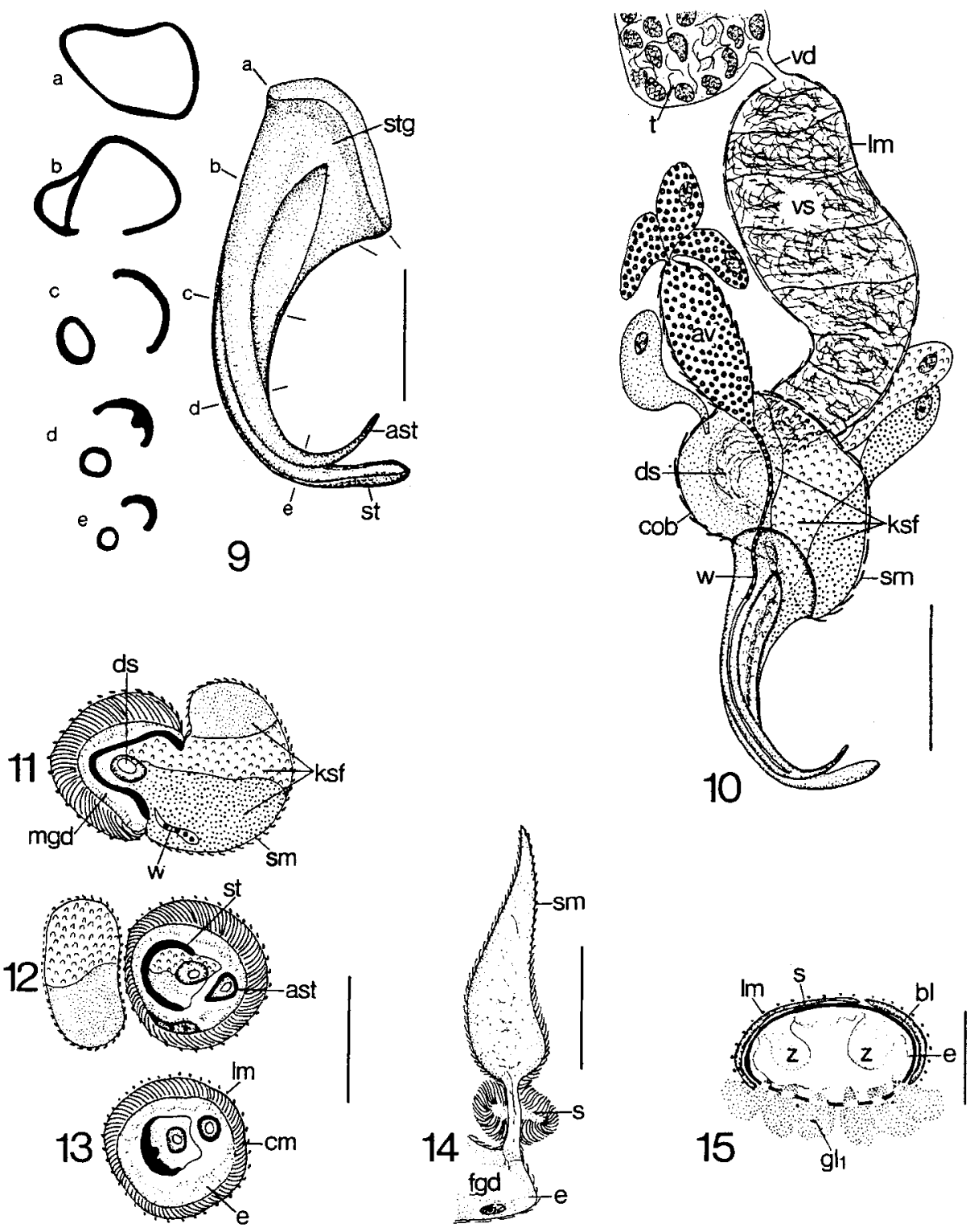

Figs 9-15. Typhlopolycystis rubra. 9. Copulatory hard structures (left: sections a-e, from different serial sections). 10. Copulatory bulb (combined). 11-13. Copulatory bulb and male genital duct with copulatory hard structures (cross-sections). 14. Seminal receptacle (sagittal section). 15. Uterus (cross-section). Scales: Fig. 9, Figs 11-14: $30 \mu \mathrm{m}$; Fig. 10: $50 \mu \mathrm{m}$; Fig. 15: $20 \mu \mathrm{m}$ 
tips are bent distally. The overall length of the copulatory hard structures is $105-120 \mu \mathrm{m}$. The diameter of the girdle is $38-44 \mu \mathrm{m}$, the proximal rim is thicker than the distal parts. In cross-section the rim is irregularly shaped (section a in Fig. 9). The girdle is split on one side. The resulting cleft becomes wider distally. Proximally, one part of the girdle is separated by a thin wall (section b). In cross-section, it is angular and represents the upper part of the $80-90 \mu \mathrm{m}$ long accessory stylet. Within the accessory stylet there is only the fine outlet of the accessory organ (Figs 10,12). The diameters of the accessory stylet are $7.5 \mu \mathrm{m}$ (proximally) and 2-3 $\mu \mathrm{m}$ (distally at the level of section e). The wall opposite the cleft splits further distad (approximately at the level of section c) to form the sheathlike stylet. Only a small, thin non-hardened septum covers the distal parts of the prostatic fascicles and the fine seminal duct (Figs 12,13). In sections, a partly hardened ridge is observed on the inside of the stylet sheath (section d in Fig. 9; Fig. 13). The walls of the distal stylet form a sheath, in which the accessory stylet may be embedded (Fig. 9, section e). Thus, the stylet serves as a guide for the accessory stylet.

At the proximal rim of the hard structure the musculature of the copulatory bulb and of the male genital duct inserts. The male canal is characterized by a strong circular muscle layer, a thin epithelium lacking nuclei, and an external longitudinal musculature (Figs 11-13). At the transition of the male genital canal and the common atrium a rostral diverticulum ( $x$ in Fig. 16) with unknown function is found. Ventrally to the diverticulum the uterus opens into the atrium. The uterus has a longitudinal muscle tunic and is distally surrounded by a strong sphincter. In cross-sections, the uterus stalk is ovoid; the proximal uterus is flattened. At the level of the sphincter, acidophilic uterine glands $\left(\mathrm{gl}_{1}\right)$ open ${ }_{i}$ the basophilic glands $\left(\mathrm{gl}_{2}\right)$ empty proximad from the sphincter. The thin nucleated uterus epithelium is characterized by 2 large dorsal papillae $\left(z_{\text {; }}\right.$ Figs $\left.15,16,22\right)$. The common genital opening is surrounded by a strong sphincter. The egg-capsules found in 2 specimens measured $300 \times 200 \mu \mathrm{m}$ (Fig. 4). No egg-filament was detected.

The short, distally sphinctered female genital duct has a thin epithelium. Dorsally, the female canal receives a minute germovitelloduct ( $y$ in Fig. 16). The short paired

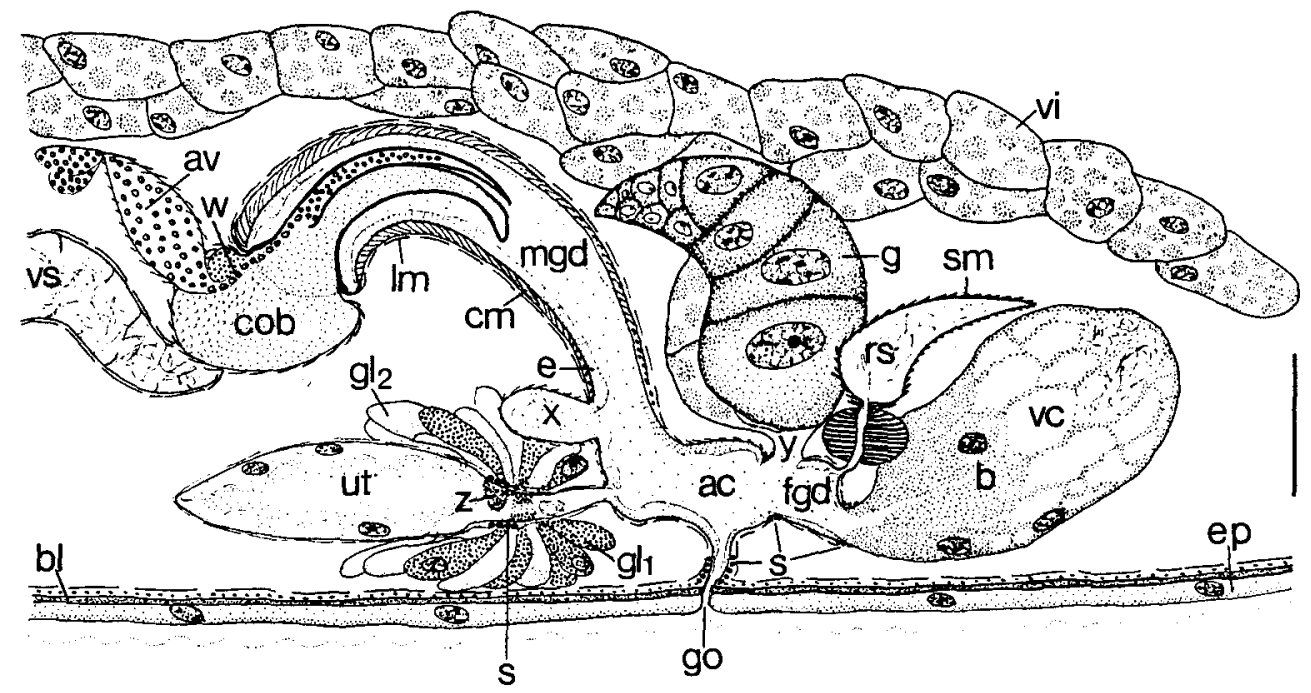

Fig. 16. Typhlopolycystis rubra. Genital organs (reconstruction from sagittal sections). Scale: $50 \mu \mathrm{m}$ 

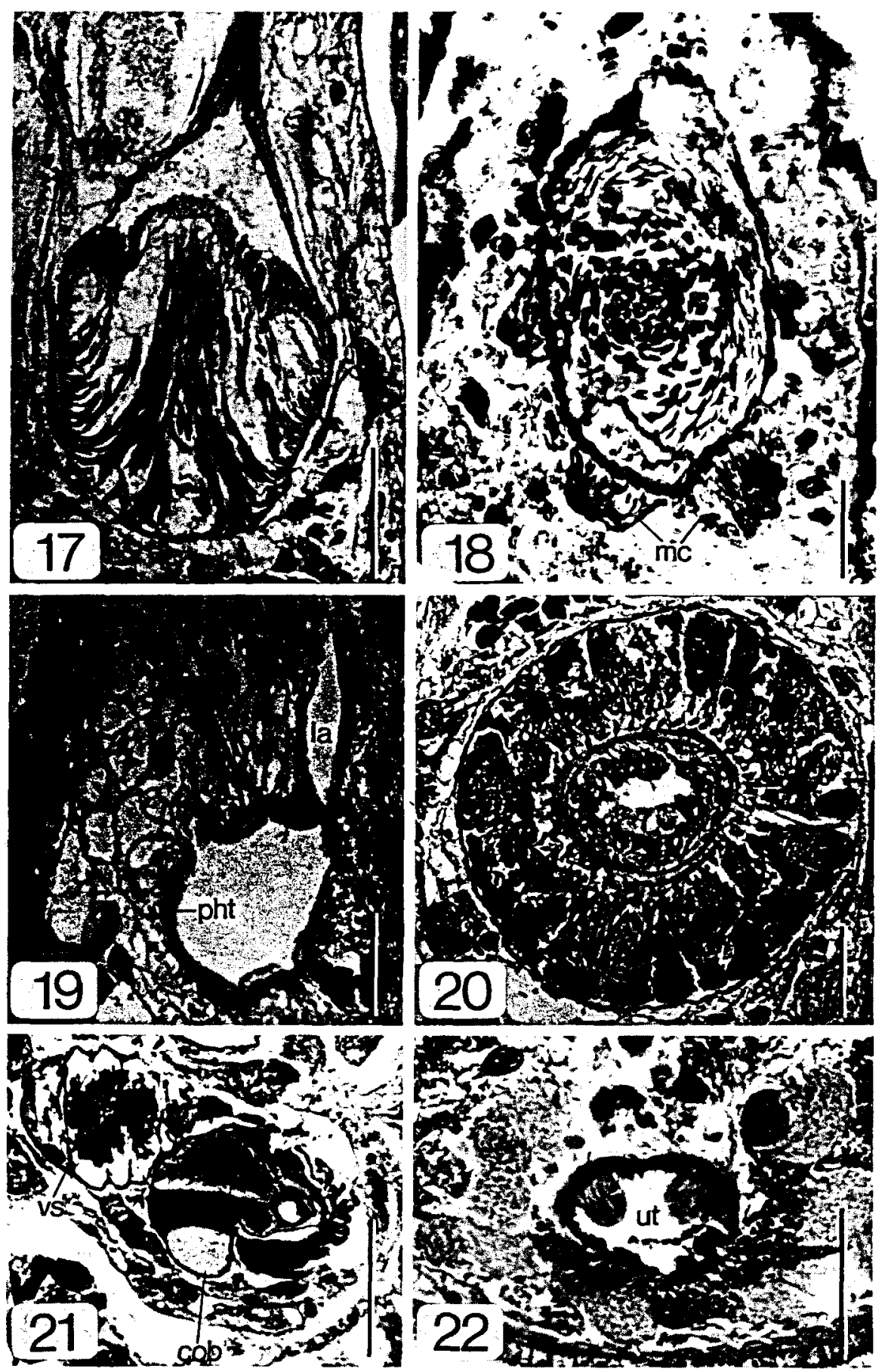

Figs 17-22. Typhlopolycystis rubra. 17 and 18. Proboscis. 19. Pharynx pouch with lacuna. 20. Pharynx bulb. 21. Copulatory bulb. 22. Uterus. (All cross-sections, except 17, sectioned longitudinally). All scales: $30 \mu \mathrm{m}$ 
vitelloducts open ventrally of the germarium. The proximal part of the germarium is bent anteriad. Further distad the female genital canal communicates with the seminal receptacle (Figs $7,8,14$ ). The $70-85 \mu \mathrm{m}$ long spindle-like receptacle is characterized by a strong distal sphincter. Proximally, it is covered by thin spiral fibres which derive from the sphincter. The fine tip of the receptacle is located near the intestinal cells. There is no indication for a pore or duct in the terminal part of the seminal receptacle. Ventrocaudally, the atrium receives the large copulatory bursa, which is also closed with a small sphincter. Distally, the bursa consists of a homogenous, basophilic tissue with numerous nuclei and few spaces. Proximally, there are large spaces filled with alien sperm (Fig. 16).

The vitellaria extend from the proboscis to the caudal adhesive glands. Near the pharynx, the vitellocytes of both sides are adjacent to one another. In one cross-section of the body the vitellaria formed a longitudinal cylinder.

\section{Discussion}

Copulatory hard structures consisting of a proximal closed girdle, which splits into a prostatic stylet and an accessory stylet, are the specific character of the Typhlopolycystis species. Until now, 4 species have been described: $T$. coeca, $T$, mediterranea, $T$.
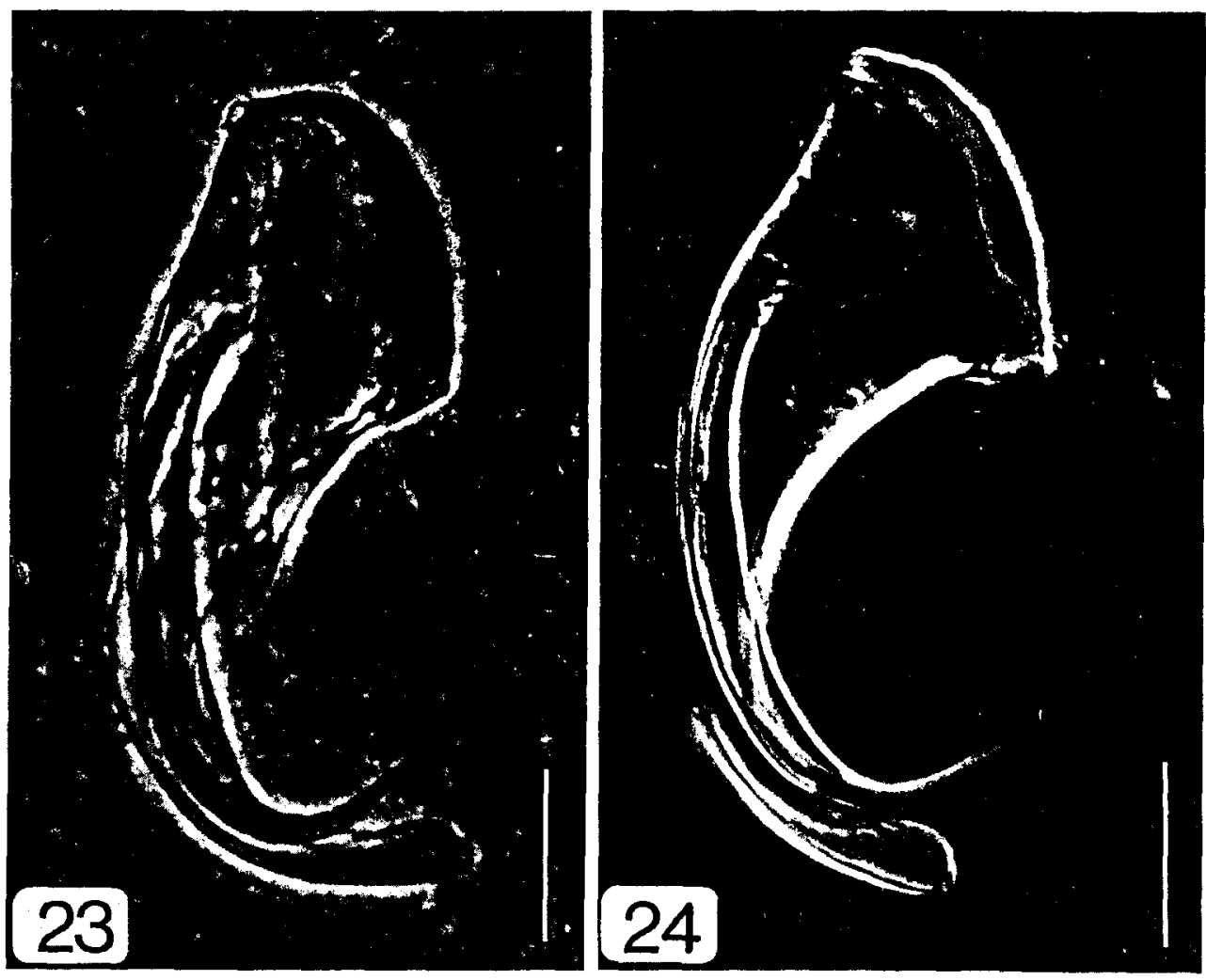

Figs 23 and 24. Typhlopolycystis rubra. Copulatory hard structures. Scales: $20 \mu \mathrm{m}$ 
coomansi and T. schockaerti (see Karling, 1956; Brunet, 1965; Schilke, 1970a; Schockaert \& Karling, 1975; Karling, 1978).

The new species $T$. rubra is characterized by the longest copulatory hard structures within the taxon Typhlopolycystis. Furthermore, both stylets are of almost equal length, whereas in the previously described Typhlopolycystis species the accessory stylet is longer than the prostatic stylet. In $T$. rubra both stylet tips are gradually curved, a feature found in $T$. mediterranea as well. In $T$. coeca, $T$. coomansi and $T$. schockaerti the accessory stylets are straight, tubiform, and taper distally. In $T$. coeca and $T$. rubra the copulatory bulb is lined with spirally arranged muscles and contains 3 prostatic fascicles. However, in $T$. coeca there are only 2 different types of secretion. In both species the prostatic glands enter the copulatory bulb subterminally in different places (see Karling, 1956; Fig. 87).

The probosces of the Typhlopolycystis species are large. The relative length of the proboscis compared to the body length is: $1: 3$ in $T$. coeca and $T$. mediterranea, $1: 4$ to $1: 3$ in $T$. coomansi, 1:5 in $T$. rubra, and 1:6 in $T$. schockaerti. The proboscis of $T$. rubra differs from that of $T$. coeca, which was studied by Schockaert $(1972 / 1973)$. There are 50 external longitudinal muscles lining the bulb in $T$. rubra (30 in $T$. coeca). The circular muscle layer of the proboscis bulb is thicker in $T$. coeca.

With respect to the female genital organs, the new species is characterized by 2 features. (1) There are 2 large epithelial papillae in the uterus, located dorsally and proximally to the uterus stalk. (2) The seminal receptacle is distally surrounded by a large sphincter. With the exception of $T$. schockaerti a spindle-like seminal receptacle has been found in all Typhlopolycystis-species. The receptacles are lined with spirally arranged musculature; however, a large sphincter is lacking in $T$. coeca, $T$. mediterranea, T. coomansi (see Karling, 1956; Fig. 89; Brunet, 1965; Fig. 11.2; Schockaert \& Karling, 1975; Fig. 43).

\section{ECOLOGY}

\section{Distribution and dynamics}

At the type locality, a total of 2780 samples of $2 \mathrm{~cm}^{3}$ were taken from various microsites of the oxic surface layer and the sulfide layer below, and particularly alongside lugworm burrows. There are no records from the surface layer where most other species of free-living Plathelminthes occur. All individuals found at type locality were 8 to $16 \mathrm{~cm}$ below the surface, in the sediment immediately surrounding the feeding pocket area or the horizontal gallery of lugworm burrows (Arenicola marina L.). The only exceptions are a single individual in the head shaft sediment at 6 to $7 \mathrm{~cm}$ depth, and another one in an experimental aggregate, of the tellinid clam Macoma balthica (L.) at a depth of 3 to $4 \mathrm{~cm}$ below the surface (Fig. 25; see Reise, 1983a).

Thus, T. rubra is virtually confined to the lowest part of lugworm burrows where it lives in coarse-grained sand. This layer of coarse particles is generated by the lugworm population (cf. Baumfalk, 1979). Surface material slides down the head shafts of burrows. Only small particles are ingested in the feeding pocket and are recycled to the surface, while coarse material accumulates at the base of burrows. The size-frequency distribution of the quartz grains is bimodal. Modes are at 0.3 and $1.2 \mathrm{~mm}$ of particle diameter. In addition to sand, there are also mollusc shells (mainly Hydrobia and small Ceras- 


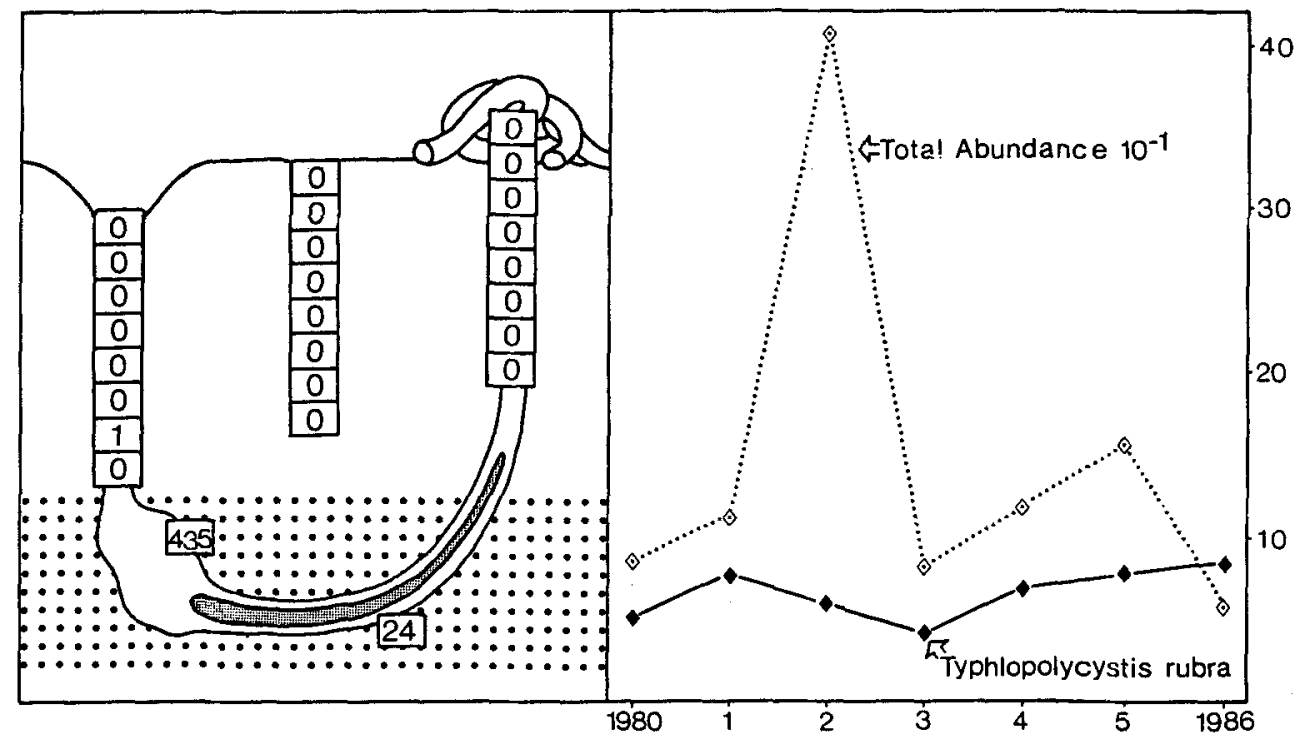

Fig. 25. Distribution (left) and dymamics (right) of Typhlopolycystis rubra on a sandy tidal flat with lugworm burrows. Boxes indicate positions of $2 \mathrm{~cm}^{3}$ samples taken from normal sediment (central column), from head and tail shaft, feeding pocket and gallery. Numbers refer to individuals found in 70 samples from June 1980 to June 1986. Layer of coarse sand is indicated. Individuals in $52 \mathrm{~cm}^{3}$ from all positions are given (right) for $T$. rubra and the sum of all free-living Plathelminthes to show interannual variability

toderma), calcium-carbonate needles from dissolved mussel shells, and organic aggregates mostly $50 \mu \mathrm{m}$ in diameter. $T$, rubra lives among these particles and distinctly aggregates at the feeding pocket areas.

A total of 97 species of free-living Plathelminthes has been encountered on the lugworm flat where $T$. rubra is abundant. The spatial niche of $T$. rubra is very small compared to these other species. Most of them populate micro-habitats at the surface or occur over a wide depth range within the sediment, particularly alongside lugworm burrows. There are only two other species, Mariplanella frisia Ax \& Heller, 1970 and Gyratricella attemsi (Graff, 1913), which are abundant near the feeding pockets and do not occur anywhere else on this tidal flat.

Notwithstanding an unusually narrow spatial niche, $T$. rubra exhibits the least interannual variability of all free-living Plathelminthes at the site (Fig. 25). Every June from 1980 to $1986_{r} 10$ samples of $2 \mathrm{~cm}^{3}$ were taken from each of the 26 micro-sites, including feeding pockets and galleries of lugworm burrows. Based on this set of data, the average density in $10 \mathrm{~cm}^{3}$ of pocket sand was 31 (range 19 to 40 ) and in galleries 2 (range 1 to 6 ). The coefficient of temporal variation was 0.24 for $T$. rubra while the other species ( $\mathrm{n}=56$ with $\geq 7$ individuals) range from 0.37 to 2.65 , with an average of 1.25. A significantly positive Spearman rank correlation of abundance over the 7 years exists only with Gyratricella attemsi, a species which is also confined to the feeding pockets.

Seasonally, T. rubra was abundant in June and October (26 individuals in $10 \mathrm{~cm}^{3}$ of pocket sand) but rare in February $\left(1\right.$ in $\left.10 \mathrm{~cm}^{3}\right)$. This may indicate an overwintering in the 


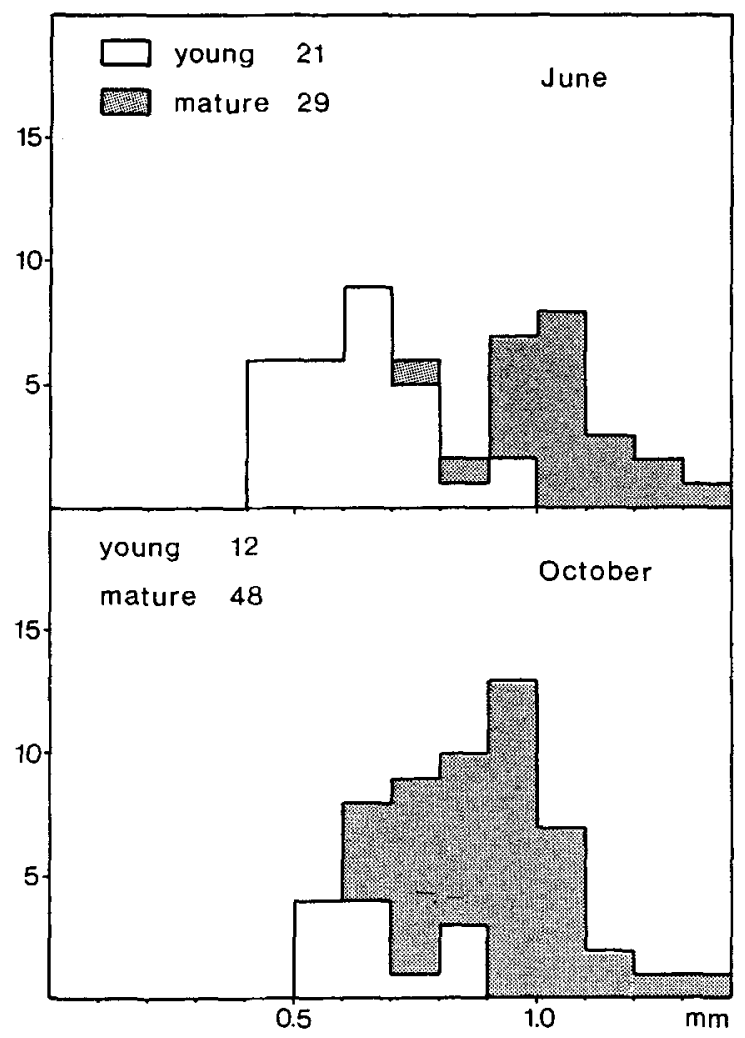

Fig. 26. Size-frequency distribution from June and October 1980. Size classes are given in $0.1 \mathrm{~mm}$ length intervals; frequency refers to individuals in $40 \mathrm{~cm}^{3}$ of pocket and gallery sand of lugworm burrows. Most young of June have attained maturity in October

egg stage within cocoons. However, size-frequency distributions of young and mature individuals in June and October (Fig. 26) suggest a persistent population throughout the year, with mature individuals surviving the winter.

\section{DISCUSSION}

The known distribution of Typhlopolycystis rubra is rather limited. In spite of intensive research on the distribution of Kalyptorhynchia (Hoxhold, 1974; Noldt, 1985, 1986; Schilke, 1970a, 1970b), and free-living plathelminth species in general (Armonies, 1987; Ax, 1977; Dittmann \& Reise, 1985; Hellwig, 1987; Wehrenberg \& Reise, 1985; Xylander \& Reise, 1984), in various littoral zones and sediments near the island of Sylt, it has been found in only two sandy tidal flats near lugworm burrows (Reise, 1984; Scherer, 1985).

This insular distribution is in contrast to the wide habitat spectra of macrofaunal species on tidal flats in the Wadden Sea (see Dankers \& Beukema, 1981). Another striking feature is the low between-year variability of the population density in $T$. rubra. In fact, it 
has the lowest rate of all free-living plathelminth species on the sand flat investigated. Although the feeding pockets may be almost unaffected by the short-term physical variability of the tidal environment, it is nevertheless subject to unpredictable behavior of the lugworm individuals. They may interrupt feeding or pumping, change the position of their feeding pockets, or even move out of the sediment (Beukema \& de Vlas, 1979; Krüger, 1971).

This irregularly deprives $T$. rubra of essential living conditions. The feeding pocket area is supplied by the lugworm with sediment from the surface, with oxic water pumped into the burrow, with mucus and excreted metabolites. This combination may cause a gardening effect for the microbiota (Hylleberg, 1975) and attracts meiofauna (Reise \& Ax, 1979; Reise, 1983b, 1984; Scherer, 1985). In the coarse grained sediment surrounding the feeding pocket, $T$. rubra will be safe from accidental ingestion, since lugworms take up only small particles (see Baumfalk, 1979). Encystment offers a possibility to endure periods of anoxia with high sulfide concentrations or when prey is absent. Thus, the ability of encystment may explain in part the observed constancy of population size.

The activity of lugworms generally ceases at low temperatures (Krüger, 1964), and then feeding pockets lose their attraction for meiofauna (Scherer, 1985). We assume that during winter, cysts of $T$. rubra are scattered throughout the coarse-grained, subsurface layer of the sediment, irrespective of the position of lugworm burrows. This might cause the low numbers of $T$. rubra in samples taken in February.

Encystment is a rare phenomenon in marine species of free-living Plathelminthes (Meixner, 1938). Recently, Armonies (1986) discovered that 11 species living in supralittoral salt marshes endure unfavorable conditions by encystment. He found that factors like humidity, salinity, temperature, and oxygen determine whether cysts are left or not. Here we report encystment for a species living in the sulfide layer of marine sediments. Cysts are easily detected because the red individuals are visible through the transparent envelope. Cysts of uncolored species, if present, probably went unnoticed.

Acknowledgements. The first author expresses his gratitude to the "Graduiertenförderung des Landes Niedersachsen". We are indebted to the German Research Federation (DFG) for financial support.

\section{LITERATURE CITED}

Armonies, W., 1986. Free-living Plathelminthes in North Sea salt marshes: adaptations to environmental instability. - J. exp. mar. Biol. Ecol. 99, 181-197.

Armonies, W., 1987. Freilebende Plathelminthes in supralitoralen Salzwiesen der Nordsee: Ökologie einer borealen Brackwasser-Lebensgemeinschaft. - Microfauna mar. 3, 81-156

Ax, P., 1977. Life cycles of interstitial Turbellaria from the eulittoral of the North Sea. In: The Alex Luther Centennial Symposium on Turbellaria. Ed. by Karling, T. G. \& Meinander, M. - Acta zool. fenn. 154, 12-20.

Baumfalk, Y. A., 1979. Heterogenous grain size distribution in tidal flat sediment caused by bioturbation activity of Arenicola marina (Polychaeta). - Neth. J. Sea Res. 13, 428-440.

Beukema, J. J., 1976. Biomass and species richness of the macrobenthic animals living on the tidal flats of the Dutch Wadden Sea. - Neth. J. Sea Res. 10, 236-261.

Beukema, J. J. \& Vlas, J. de, 1979. Population parameters of the lugworm, Arenicola marina, living on tidal flats in the Dutch Wadden Sea. - Neth. J. Sea Res. 13, 331-353.

Brunet, M., 1965. Turbellaries Calyptorhynques de substrats meubles de la région de Marseille. Recl. Trav. Stn Endoume 39, 127-219.

Dankers, N. \& Beukema, J. J., 1981. Distributional patterns of macrozoobenthic species in relation to 
some environmental factors. In: Invertebrates of the Wadden Sea. Ed. by Dankers, N., Kühl, H. \& Wolff, W. J. Balkema, Rotterdam, 69-103. (Rep. Wadden Sea working group 4.)

Dittmann, S. \& Reise, K., 1985. Assemblage of free-living Plathelminthes (Turbellaria) on an intertidal mud flat in the North Sea. - Microfauna mar. 2, 95-115.

Hellwig, M., 1987. Ökologie freilebender Plathelminthen im Grenzraum Watt-Salzwiese lenitischer Gezeitenküsten. - Microfauna mar. 3, 157-248.

Hoxhold, S., 1974. Populationsstruktur und Abundanzdynamik interstitieller Kalyptorhynchia. Mikrofauna Meeresboden 41, 1-134.

Hylleberg, J., 1975. Selective feeding by Abarenicola pacifica with notes on Abarenicola vagabunda and a concept of gardening in lugworms. - Ophelia 14, 113-137.

Karling, T. G., 1956. Morphologisch-histologische Untersuchungen an den männlichen Atrialorganen der Kalyptorhynchia (Turbellaria). - Ark. Zool. (Andr. Ser.) 9, 188-279.

Karling, T. G., 1978. Anatomy and systematics of marine Turbellaria from Bermụda. - Zool. Scr. 7 . 225-248.

Krüger, F., 1964. Messungen zur Pumptätigkeit von Arenicola marina L. im Watt. - Helgoländer wiss. Meeresunters. 11, 70-91.

Krüger, F., 1971. Bau und Leben des Wattwurmes Arenicola marina. - Helgoländer wiss. Meeresunters. 22, 149-200.

Lewin, R., 1983. No dinosaurs this time. - Science, N. Y. 221, 1168-1169.

May, R. M., 1986. How many species are there? - Nature, Lond. 324, 514-515.

Meixner, J., 1938. Turbellaria (Strudelwürmer). I. - Tierw. Nord- u. Ostsee 4b, 1-146.

Noldt, U., 1985. Typhlorhynchus syltensis n. sp. (Schizorhynchia, Plathelminthes) and the adelphotaxa-relationship of Typhlorhynchus and Proschizorhynchus. - Microfauna mar. 2, 347-370.

Noldt, U., 1986. Kalyptorhynchia (Plathelminthes) aus dem sublitoralen Küstenbereich der Nordseeinsel Sylt. Diss. Univ. Göttingen, $221 \mathrm{pp}$.

Reise, K., 1983a. Sewage, green algal mats anchored by lugworms, and the effects on Turbellaria and small Polychaeta. - Helgoländer Meeresunters. 36, 151-162.

Reise, K., 1983b. Biotic enrichment of intertidal sediments by experimental aggregates of the deposit-feeding bivalve Macoma balthica. - Mar. Ecol. Prog. Ser. 12, 229-236.

Reise, K., 1984. Free-living Platyhelminthes (Turbellaria) of a marine sand flat: an ecological study. Microfauna mar. 1, 1-62.

Reise, K., 1985. Tidal flat ecology. Springer, Bèrlin, 192 pp.

Reise, K. \& Ax, P., 1979. A meiofaunal "Thiobios" limited to the anaerobic sulfide system of marine sands does not exist. - Mar. Ecol. Prog. Ser. 54, 225-237.

Scherer, B., 1985. Annual dynamics of a meiofauna community from the "sulfide layer" of a North Sea sand flat. - Microfauna mar. 2, 116-161.

Schilke, K, 1970a. Kalyptorhynchia (Turbellaria) aus dem Eulitoral der deutschen Nordseeküste. Helgoländer wiss. Meeresunters. 21, 143-265.

Schilke, K., 1970b. Zur Morphologie und Phylogenie der Schizorhynchia (Turbellaria, Kalyptorhynchia). - Z. Morph. Tiere 67, 118-171.

Schockaert, E. R., 1972/1973. Monografie der Polycystididae (Turbellaria, Kalyptorhynchia). Diss. Univ. Gent, 230 pp.

Schockaert, E. R. \& Karling, T. G., 1975. Anatomy and taxonomy of some species of Polycystididae (Turbellaria, Kalyptorhynchia) from N. Atlantic and Mediterranean coastal areas. - Zool. Scr. 4, $133-143$.

Wehrenberg, C. \& Reise, K., 1985. Artenspektrum und Abundanz freilebender Plathelminthes in sublitoralen Sänden der Nordseeinsel Sylt. - Microfauna mar. 2, 163-180.

Wilson, E. O., 1985. Time to revive systematics. - Science, N. Y. 230, 1228.

Wolff, W. J., 1983. Ecology of the Wadden Sea. Balkema, Rotterdam. 1-3.

Xylander, W. E. R. \& Reise, K., 1984. Free-living Plathelminthes (Turbellaria) of a rippled sand bar and a sheltered beach: a quantitative comparison at the island of Sylt (North Sea). - Microfauna mar. 1, 257-277. 